\title{
Follower Effects In The Visionary Leadership Process
}

Sooksan Kantabutra, Mahidol University, Thailand

Gayle C. Avery, (Email: gsyle.avery@mgsm.edu.au), Macquarie Graduate School of Management, Australia

\begin{abstract}
This study examined relationships between followers' use of their leader's vision and their own emotional commitment to the vision, and associated organizational performance in retail stores, exploring the rarely investigated follower role in a visionary leadership process. Findings endorse the importance of vision guiding and emotional commitment to a vision. Both were significantly associated with organizational performance, although emotional commitment was more important.
\end{abstract}

\section{INTRODUCTION}

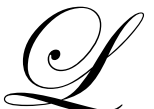

eadership and followership are fundamental roles that individuals shift into and out of under various conditions (Daft, 2005). Since most individuals, even those with high authority, have some kind of boss or supervisor, individuals are more often followers than leaders (Kelly, 1988). Yet, research into leadership has traditionally focused on either individual leaders or the broad strategic leadership sphere (Avery, 2004). More specifically, research into vision-based leadership, recommended for organizations to remain competitive in a fast changing world (Bass, 1990; Conger, 1991; Conger \& Kanungo, 1987; Tichy \& Devanna, 1986), has generally focused on four aspects of the vision: development, articulation, communication, and implementation (e.g. Nanus, 1992; Quigley, 1993; Robbins \& Duncan, 1988; Sashkin, 1992; Wall, Solum, \& Sobol, 1992; Westley \& Mintzberg, 1989). The follower role in a visionary process has been largely overlooked by researchers (House \& Aditya, 1997; Howell \& Shamir, 2005; Kantabutra \& Avery, 2002).

In the visionary leadership process, understanding follower variables is particularly important given that the intensified challenge of gaining commitment from followers using a single vision in a global world. Two follower variables are commonly identified in the visionary leadership literature: followers' use of their leader's vision to guiding daily operations and followers' emotional commitment to the vision. Accordingly, eight hypotheses linking follower vision guiding and follower emotional commitment to vision with organizational performance, as measured by customer and staff satisfaction, were developed and tested in retail stores. Research methodology, findings, as well as future research directions are discussed below.

\section{DEFINING VISION}

Research into vision-based leadership is complicated by a lack of clear vision definition (Kantabutra \& Avery, 2002), despite the fact that vision-based leadership has been said to positively impact organizational performance (e.g. Bass, 1990; House \& Aditya, 1997; Isenberg, 1987; Maccoby, 1981; Mensal \& Gerguoy, 1984; Peters, 1987; Slater, 1993). Terms like mission, philosophy, vision, and values are often used interchangeably. Avoiding the confusing definitional issue altogether, Baum, Locke, \& Kirkpatrick (1998) accepted the "vision" as defined by each leader, arguing that it is the leader's actual vision that guides his/her behavior. This approach was also adopted in this study because each leader develops a vision in his/her own way (Nanus, 1992), and because a leader's style, vision content, and operating context vary widely (Westley \& Mintzberg, 1989). Thus, building on Baum et al. this paper considers the effects of visionary tools that the leader actually employs, rather than adopting a possibly unrelated theoretical definition. 
Vision works in various ways. It provides a link between present and future, serves to energize and motivate followers toward the future, provides meaning for people's lives and work, and sets a standard of excellence in an organization (Avery, 2004; Daft \& Lengel, 1998; Nanus, 1992). A guiding star to draw everyone along the same path toward the future, vision can energize people and garner commitment from followers (Daft, 2005). The following section discusses follower variables of using vision to guide their work and emotional commitment to a vision.

\section{DEFINING FOLLOWER VARIABLES}

Management authors tend to focus on top leaders who capture the hearts and minds of their followers with their images of some desired future state, although vision-based leadership can occur at all levels of an enterprise (Avery, 2004). These extraordinary leaders are expected to provide a clear vision of the future because their power depends on acceptance, sharing, and commitment to the vision by the followers. Visionary leadership adds strong emotional aspects and a view of a desired future to motivate followers, allowing the leader to take on heroic proportions (Maccoby, 2000). From the few writers discussing follower roles in the visionary leadership process, the following variables emerged: the vision guides followers' work (Conger \& Kanungo, 1988; Lipton, 1996); and followers are emotionally committed to the vision (Collins \& Porras, 1994; House \& Shamir, 1993; Lipton, 1996). Each is discussed below.

\section{Vision Guiding}

A visionary leader depends on followers who will accept and help execute the vision (Daft, 2005). Followers of a vision-based leader are not expected to be passive, but have a responsibility to participate in the group, work towards the vision, and make their voices heard in influencing what is accomplished (Avery, 2004). When every follower understands and embraces a vision, the organization becomes self-adapting (Daft, 2005). Although each individual acts independently, everyone is working in the same direction. In doing so, followers' use of their leader's vision in guiding their work is important (e.g. Conger \& Kanungo, 1988; Lipton, 1996; Senge, 1990; Sergiovanni, 1990; Shamir, House, \& Arthur, 1993). One function of a vision is to facilitate decision-making, initiative, and discretion by followers at all levels (Yukl, 1998).

Vision-based leaders understand that they cannot turn their visions into reality alone (Kantabutra \& Avery, 2002). They need help and support from their followers. Vision-based leaders therefore empower their followers by assigning tasks that lead to successively greater positive experiences and heightened self-confidence, thus persuading followers of their own capabilities and creating an environment of positive emotions and heightened excitement (Lussier \& Achua, 2001). In giving power to followers to perform tasks, there is a need for common direction or purpose that can be provided by a guiding vision. Knowing the organization's central purpose and objectives helps followers determine what behavior is appropriate, important, or trivial. Therefore, whether and how followers use the vision to guide their work could affect both individual and collective performance outcomes. Vision guiding was defined in this study as the extent to which employees use their store manger's vision to guide their daily operations.

\section{Emotional Commitment To Vision}

Visionary leadership is effective only if followers become committed to the vision promoted by the leader (Avery, 2004). Therefore, the vision must meet followers' desires. Research has also shown that effective visionary leaders are in tune with their followers' needs (Gilmore \& Shea, 1997). Vision-based leaders obtain their considerable power from various sources, two of which are their appealing vision and followers' emotional attachments to the vision (Howell \& Shamir, 2005; Shamir, House, \& Arthur, 1993). They motivate and excite followers to be selfmotivating through the follower's attraction to the vision and identification with the group's values, and followers come to see their work as meaningful and important (Bono \& Judge, 2003). Indeed, visionary leaders motivate their followers partly by increasing the intrinsic value of effort (Shamir, House, \& Arthur, 1993). This occurs because the effort itself reflects certain values and makes a moral statement. Participating in the activity becomes more meaningful to the follower, and increases the attraction of being part of the group. The vision thus seems very worthwhile achieving. 
Emotional commitment from followers to their leader's vision is considered important for a vision to take effect, because when followers are committed, they tend to be willing to work toward the vision (Collins \& Porras, 1994; Lipton, 1996; Shamir, House, \& Arthur, 1993). Vision inspires people by transcending the bottom line (Nanus, 1992). When followers are emotionally committed, they will be willing, even eager, to commit voluntarily and completely to something that enables their own organization to grow and progress. That is why a firm's scientists and engineers may be willing to work day and night to achieve an important technological breakthrough or why middle managers in some companies are willing to forego their vacation year after year to ensure their firm's success (Nanus, 1992). Therefore, whether and how followers are emotionally committed to their leader's vision could impact individual and collective performance outcomes. Emotional commitment was defined in this study as the extent to which employees say that they believe in their store manager's vision and will do whatever it takes to achieve the vision.

\section{PERFORMANCE MEASURES}

Customer satisfaction (e.g. Bird, 1995; Gates, 2000; Sitzia \& Wood, 1997) and employee satisfaction (e.g. Anderson, 1984; Barbin \& Boles, 1996; Tompkins, 1992; van Dyck, 1996; Yeung \& Berman, 1997) have been cited as performance indicators in various business organizations. Therefore, they were adopted in this study as performance measures. Another reason for the adoption is that both customer and employee satisfaction are more responsive to leaders' behavior within the short time frame of the study than financial measures, and were not as difficult to obtain from small businesses. In addition, employee satisfaction is considered closely related to customer satisfaction (e.g. Atchison, 1999; Faye \& Diane, 1995; Hausfeld, Gibbons, Holtmeier, Knight, Schulte, Stadtmiller, \& Yeary, 1994). This is attributed to customer satisfaction or dissatisfaction developing when a customer comes in contact with staff (Evans \& Lindsay, 1996). Customer satisfaction is also said to be an indicator of other critical measures of business performance such as customer loyalty, profit, market share, and growth (Anderson, Fornell, \& Lehman, 1994; Bolton \& Drew, 1991; Buzzell \& Gale, 1987; Fornell \& Wernerfelt, 1987; Hurley \& Estelami, 1998; Rust \& Zahorik, 1993).

Usually, customer and employee satisfaction are significantly correlated. Therefore, staff vision guiding and staff emotional commitment were tested against each performance measure separately to prevent autocorrelation effects. It must be noted that the authors do not suggest that customer and employee satisfaction exhaustively explain organizational performance.

\section{HYPOTHESES}

How follower vision guiding, follower emotional commitment to vision, and organizational performance are related is not yet well understood. Figure 1 depicts a model tested in this study that proposes a link between staff vision guiding and staff emotional commitment to vision, and organizational performance derived from the literature, using variables relating to the retail sector.

Two domains - vision guiding and emotional commitment to the vision - shown in Figure 1 are represented in a main effects path model using retail performance measured by customer and staff satisfaction as the outcome variables. Vision guiding and emotional commitment to vision can be expected to have direct effects, as shown by the solid lines, on customer and staff satisfaction. Accordingly, the following hypotheses were generated. All hypotheses are directional because the literature emphasizes that both vision and followers espousing a vision create a positive impact on organizational performance.

$\mathbf{H}_{1}$ : $\quad$ There is a positive relationship between overall customer satisfaction and stores having a vision.

$\mathbf{H}_{2}$ : There is a positive relationship between overall staff satisfaction and stores having a vision.

$\mathbf{H}_{3}$ : There is a positive correlation between staff vision guiding and customer satisfaction.

$\mathbf{H}_{4}$ : There is a positive correlation between staff vision guiding and staff satisfaction.

$\mathbf{H}_{5}$ : There is a positive correlation between staff emotional commitment to vision and customer satisfaction.

$\mathbf{H}_{6}: \quad$ There is a positive correlation between staff emotional commitment to vision and staff satisfaction. 
$\mathbf{H}_{7}$ : Staff vision guiding and staff emotional commitment to vision are positively, directly associated with customer satisfaction.

$\mathbf{H}_{\mathbf{8}}$ : Staff vision guiding and staff emotional commitment to vision are positively, directly associated with staff satisfaction.

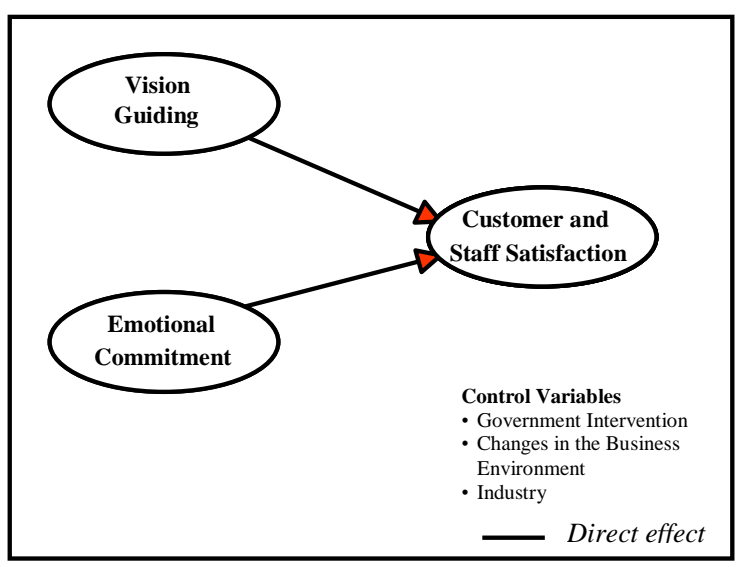

Figure 1: Staff vision guiding and emotional commitment -organizational performance path model showing variables and measures for the retail sector.

\section{METHOD}

Since external factors such as industry-wide government intervention and changes in the business environment could also affect the visionary leadership process (Westley \& Mintzberg 1989), these factors were controlled in the model by conducting the study in a specific retail industry, at a specific period in time, and therefore under ostensibly the same business environment. In doing so, the external factors were largely controlled.

The store sample was drawn from apparel stores in Sydney, Australia, that sell brand-new, finished clothing products for individual use, excluding shoes and accessories. Both independent stores and those belonging to a parent company were sampled. All were located in a shopping mall and had their own identity, being in a clearly-defined walled area. Nineteen major shopping centers were selected and all qualifying stores approached. Of these, 111 stores (70\%) agreed to participate, with 48 stores (30\%) declining. From the participating stores, store managers, and up to three staff and three customers were interviewed. Three staff members per store represented over $50 \%$ of each store's staff population on average, given that $70 \%$ of the Australian Retailer Association's members in 2001, in New South Wales, employed five or fewer employees on average (http://www.ara.com.au/). Since the customer population was unknown, a minimum of three customers per store was adopted as the customer sample size, consistent with the staff sample.

Store managers are those fulltime store employees who manage their own stores and are stationed there daily. The latter criterion was important because the study was interested in the effects of one manager's vision only. The 148 staff interviewed included fulltime, parttime, and casual employees working under the store managers, and the 214 customers surveyed were individuals who were observed buying a product or service during the researcher's visit. If no customer was observed buying during the researcher's visit, the researcher returned later until three customers had agreed to participate or three visits were made to the store. 


\section{Data Collection And Analysis}

Three different questionnaires were used for store managers, staff, and customers. A nine-point ratio scale underlay all questionnaire items measuring staff vision guiding, staff emotional commitment, and customer and staff satisfaction domains. Three trained research assistants interviewed store managers and their staff and customers. Refusal rates for staff and customers were 56\% and 36\% respectively. Those who refused were not reapproached.

The store manager questionnaire collected demographic data, information on vision including asking the store managers whether they had a vision. The staff questionnaire asked about vision guiding and staff emotional commitment to the store manager's vision. Vision guiding was operationally defined as the extent to which an employee used his/her store manager's vision to guide his/her daily activities. Staff emotional commitment was operationally defined as the extent to which an employee believed in his/her store manager's vision and did whatever it takes to achieve the vision. Staff also responded to six components of job satisfaction based on criteria developed by Slavitt, Stamps, Piedmont, \& Hasse (1986). These measures were pay (dollar remuneration and fringe benefits), autonomy (job-related independence, initiative, and freedom), task requirements (job activities that must be done), organizational policies, interaction (formal/informal, social and professional contact at work), and professional status (overall importance of job through self/other's perspective). The customer questionnaire collected data on 14 items measuring customer satisfaction with services at the store using criteria from Hackl, Scharitzer, \& Zuba (2000). The measures were availability of staff for information and advice, friendliness of staff, overall decoration of store, presentation of goods, cleanliness of the store, quality of goods, richness of choice, waiting time for checkout, methods of payment, price labeling, availability of special offers and sales, shopping hours, prices, and shelf/rack layout.

Summing scores of subvariables for each measurement domain was considered justified because convergent and discriminant validity were sufficiently represented $(\mathrm{p}<0.05)$, although some subvariables designed to measure one construct correlated with other subvariables intended to measure other constructs. This is possible because convergent and discriminant validity are never all-or-nothing constructs, making it impossible to "prove" the construct validity of a measured variable (Stangor, 1998). Relevant scales associated with staff emotional commitment, and customer \& staff satisfaction were unidimensional (coefficient values $>0.3$, see Taris \& Bok, 1998). All scales indicated reliability values exceeding, or very close to, 0.8 (Fornell \& Larcker, 1981). Vision guiding was not tested for unidimensionality and scale reliability because it is a single item. By convention, one-tailed tests were adopted at the $5 \%$ level of significance for testing all hypotheses.

\section{RESULTS}

In total, 111 store manager questionnaires were completed, 148 staff questionnaires and 214 customer questionnaires. Store managers had been with the stores for 3.39 years on average. Staff members consisted of fulltime (30\% of respondents), part-time (23\%), and casual (47\%) respectively, and had worked in their stores for an average of 2.64 years. Stores averaged 6.29 staff members in total, including 2.34 full-time, 2.47 part-time, and 4.35 causal staff members. The average number of employees in the surveyed stores was slightly higher than the Australian Retailer Association average of 5. This may have been because some smaller stores declined to participate because of their lower staff numbers.

Among the 111 participating stores, 81 (73\%) store managers reported having a vision for their store. Averaged total scores and pooled standard deviations for the major dependent and independent variables are presented in Table 1. Of all the means, a higher value indicates a better result.

The chi-squared values resulting from testing Hypotheses 1 and 2 indicated a significant association between overall customer and staff satisfaction, and stores with a vision $\left(\chi^{2}=34.72\right.$ and 15.69 respectively). Hypothesis 3 was tested using correlation, yielding no signification relationship. Similarly, Hypothesis 4 was tested, resulting in a significant, positive relationship between staff vision guiding and staff satisfaction $(r=0.34)$. In testing Hypotheses 5 and 6, significant, positive relationships were found between staff emotional commitment to vision and both customer and staff satisfaction ( $r=0.33,0.5$ respectively). For Hypothesis 7 , the regression analysis performed between staff 
vision guiding and staff emotional commitment to vision, and customer satisfaction, revealed a significant, positive association between staff emotional commitment and customer satisfaction $(\beta=0.39)$. In testing Hypothesis 8 , a regression between staff vision guiding and staff emotional commitment to vision, and staff satisfaction, suggested that only staff emotional commitment was significantly, positively associated with staff satisfaction $(\beta=0.44)$. The staff vision guiding effect on staff satisfaction $(r=0.34)$ was masked fully by staff emotional commitment effect.

Table 1: Means And Standard Deviations For Major Variables

\begin{tabular}{llc}
\hline Variables & Mean & Standard Deviation \\
Vision Guiding & 14.39 & 5.42 \\
Emotional Commitment & 15.67 & 2.82 \\
Staff Satisfaction & 75.7 & 15.03 \\
Customer Satisfaction & 95 & 15.35 \\
\hline
\end{tabular}

In summary, Hypotheses 1, 2, 4, 5, and 6 were accepted. Hypothesis 3 was not accepted, and Hypotheses $7-$ 8 were partially supported. Only staff emotional commitment had a positive, direct relationship with customer satisfaction. An indirect, positive significant relationship was found between staff vision guiding and staff satisfaction, while staff emotional commitment had a positive, direct association with staff satisfaction.

\section{DISCUSSION}

Supporting prior claims that espousing a vision creates positive effects on organizational performance, stores with a vision are associated with enhanced customer and staff satisfaction. Looking more closely at the results, staff who used their store manager's vision to guide their daily operations reported enhanced staff satisfaction, lending broad support to the views that: (a) followers' use of their leader's vision as a guide in their work is important to organizational performance (e.g. Conger \& Kanungo, 1988; Lipton, 1996; Senge, 1990; Sergiovanni, 1990; Shamir et al., 1993); (b) a vision can facilitate decision-making, initiative, and discretion by followers (Yukl, 1998). The finding also implies that the more staff members use their store manager's vision to guide their daily activities, the better the organizational performance as measured by staff satisfaction. This may be because staff are clear about the long-term direction of their organization through the store's vision, and act within their roles and responsibilities to follow it, thus contributing to turning the vision into reality. Previous research has shown that clarity is a significant attribute of visions (Kantabutra \& Avery, 2003).

The results revealed that staff emotional commitment to their store manager's vision is critical to enhanced organizational performance as measured by both customer and staff satisfaction. Moreover, staff emotional commitment to a vision is associated with customer satisfaction, taking into account the staff vision guiding. These findings suggest that the more staff members believe in their store manager's vision and do whatever it takes to achieve the vision, the higher the customer and staff satisfaction. This implies that when followers share their store manager's vision, they will try to do their best to achieve it and this possibly enhances both their own and customer satisfaction. Satisfied customers might also motivate employees and raise the intrinsic value of effort. This virtuous spiral benefits the store where staff behavior aligns with the vision.

One may question how the attachment to the leader's vision and performance might arise. One explanation is that employees, who are satisfied with their jobs and/or their relationship with their manager, more easily accept and share their manager's vision. This is akin to Howell \& Shamir's (2005) concept of a personalised relationship with a leader. Some employees become emotionally attracted to the leader as person, and then become influenced by the leader's vision. Under a socialized view of attachment, employees are attracted to workplaces where they share the vision and values of the leader (Howell \& Shamir, 2005). 
An interactive effect found between staff vision guiding and staff emotional commitment on staff satisfaction implies that both staff vision guiding and staff emotional commitment are important to organizational performance. In this study, staff emotional commitment to vision was found to be more important to organizational performance via staff satisfaction. This suggests that contribution to improving store performance from vision-guided staff members can be enhanced when they are emotionally committed to the vision.

The notion gains support that followers' emotional commitment to their leader's vision is important for a vision to take effect, because when followers are committed, they tend to be willing to work toward the vision (Collins \& Porras, 1994; Lipton, 1996). The proposition that when followers are emotionally committed, they will be willing, even eager, to commit voluntarily and completely to something that enables their own organization to grow and progress has also been endorsed (Nanus, 1992).

\section{FUTURE DIRECTIONS}

Many opportunities for future researchers are pointed out. Although the importance of espousing a vision to organizational performance has been endorsed by this study's findings, future researchers may take into account vision quality in examining staff vision guiding and staff emotional commitment to vision, because quality of vision has been found to have an impact on organizational level performance (Baum et al., 1998). Some qualities (e.g. desirability, challenge) in a vision might be easier to gain emotional commitment from staff and be used by them than others. Moreover, the present study only confirms the significance of staff vision guiding and staff commitment to vision. How staff use their leader's vision to guide their daily activities and how they become emotionally committed to the vision are still unknown, indicating areas for future research.

The interaction found between staff emotional commitment and staff vision guiding indicates that the extent to which an employee is emotionally committed to his/her leader's vision is highly important to organizational performance. It might be interesting to investigate possible relationships between staff emotional commitment and their personal visions, since the similarity between leader vision and staff personal visions has been emphasized as key to organizational performance (e.g. Reardon, 1991; Sashkin, 1985; Senge, 1990). It can be expected that the more a leader and followers share a vision, the more followers are emotionally committed to the vision, impacting organizational performance in positive ways.

Future studies might also test the impact of both vision guiding and emotional commitment to vision in larger, more complex organizations, and in different cultures. Lastly, financial performance measures can be included as measures in future studies.

\section{CONCLUSIONS}

The findings suggest that simply having a vision is positively related to organizational performance as measured by both staff and customer satisfaction. Using the manager's vision to guide daily activities is associated with enhanced staff satisfaction compared with staff who do not use vision to guide their behavior. Staff emotional commitment to their store manager's vision is associated with enhanced organizational performance through both customer and staff satisfaction. Staff emotional commitment to the vision is even more important to organizational performance than staff vision guiding.

\section{REFERENCES}

1. Anderson, C. H. 1984. Job Design: Employee Satisfaction and Performance in Retail Stores. Journal of Small Business Management, 22(4): 9-16.

2. Anderson, E. W., Fornell, C., \& Lehman, D. R. 1994. Customer Satisfaction, Market Share, and Profitability: Findings from Sweden. Journal of Marketing, 58(July): 53-66.

3. Atchison, T. 1999. The Myths of Employee Satisfaction. Healthcare Executive, March/April: 19-23.

4. Avery, G. C. 2004. Paradigms of leadership: Theory and cases. Thousand Oaks: Sage. 
5. Barbin, B. J. \& Boles, J. S. 1996. The Effects of Perceived Co-worker Involvement and Supervisor Support on Service Provider Role Stress, Performance and Job Satisfaction. Journal of Retailing, 72(1): 57-75.

6. Bass, B. M. 1990. Bass and Stogdill's handbook of leadership: Theory, research, and managerial applications ( $3^{\text {rd }}$ ed.) New York: Free Press.

7. Baum, J. R., Locke, E. A., \& Kirkpatrick, S. A. 1998. A Longitudinal Study of the Relation of Vision and Vision Communication to Venture Growth in Entrepreneurial Firms. Journal of Applied Psychology, 83: 4354.

8. Bird, A. 1995. Performance Measurement for the Financial Services Industry. Community Banker, 1(5): 710 .

9. Bolton, R. N. \& Drew, J. H. 1991. A Multistage Model of Customers' Assessments of Service Quality and Value. Journal of Consumer Research, 17(March): 375-384.

10. Buzzell, R. D. \& Gale, B. T. 1987. The PIMS principles: Linking strategy to performance. New York: Free Press.

11. Collins, J. C. \& Porras, J. I. 1994. Built to last: Successful habits of visionary companies. London: Century.

12. Conger, J. A. 1991. Inspiring Others: The Language of Leadership. Academy of Management Executive, 5(1): 31-45.

13. Conger, J. A. \& Kanungo, R. N. 1987. Toward a Behavioral Theory of Charismatic Leadership in Organizational Settings. Academy of Management Review, 12: 637-647.

14. Conger, J. A. \& Kanungo, R. N. 1988. Charismatic leadership: The elusive factor in organizational effectiveness. San Francisco, CA: Jossey-Bass.

15. Daft, R. L. 2005. The leadership experience. Mason, Ohio: Thomson South-Western.

16. Daft, R. L. \& Lengel, R. H. 1998. Fusion leadership: Unlocking the subtle forces that change people and organizations. San Francisco: Berrett-Koehler.

17. Evans, J. R. \& Lindsay, W. M. 1996. The management and control of quality. MN: West.

18. Faye, M. \& Dianne, R. L. 1995. Transformational Leadership and Job Satisfaction. Nursing Management, 26(9): 64JJ-64NN.

19. Fornell, C. \& Larcker, D. 1981. Evaluating Structural Equation Models with Unobservable Variables and Measurement Error. Journal of Marketing Research, 18(February): 39-50.

20. Fornell, C. \& Wernerfelt 1987. Defensive Marketing Strategy by Customer Complaint Management: A Theoretical Analysis. Journal of Marketing Research, 24(November): 337-346.

21. Gates, S. 2000. Strategic Performance Measurement Systems: Translating Strategy Into Results. The Bank of America Journal of Applied Corporate Finance, 13(3): 44-59.

22. Gilmore, T. N. \& Shea, G. P. 1997. Organizational Learning and the Leadership Skill of Time Travel. Journal of Management Development, 16(4): 302-311.

23. Hackl, P., Scharitzer, D., \& Zuba, R. 2000. Customer Satisfaction in the Austrian Food Retail Market. Total Quality Management, 11(7): S999-S1006.

24. Hausfeld, J., Gibbons, K., Holtmeier, A., Knight, M., Schulte, C., Stadtmiller, T., \& Yeary, K. 1994. Selfstaffing: Improving Care and Staff Satisfaction. Nursing Management, 25(10): 74.

25. House, R. J. \& Aditya, R. N. (1997) The social scientific study of leadership: Quo vadis? Journal of Management, 23(3), 409-473.

26. Howell, J. M. \& Shamir, B. 2005. The role of followers in the charismatic leadership process: Relationships and their consequences, Academy of Management Review, 30(1): 96-112.

27. Hurley, R. F. \& Estelami, H. 1998. Alternative Indexes for Monitoring Customer Perceptions of Service Quality: A Comparative Evaluation in a Retail Context. Journal of Academy of Marketing Science, 26(3): 209-221.

28. Isenberg, D. J. 1987. The Tactics of Strategic Opportunism. Harvard Business Review, March-April: $92-97$.

29. Kantabutra, S. \& Avery, G.C. 2002. Proposed Model for Investigating Relationships Between Vision Components and Business Unit Performance. Journal of the Australian and New Zealand Academy of Management, 8(2): 22-39.

30. Kantabutra, S. \& Avery, G. C. 2003. Enhancing SME performance through vision-based leadership: An empirical study. Conference Paper in Proceedings: Proceedings of the 16th Annual Conference, 2003 Small Enterprise Association of Australia \& New Zealand.

31. Kelly, R. E. 1988. In Praise of Followers. Harvard Business Review,(November/December): $142-148$. 
32. Lipton, M. 1996. Demystifying the Development of an Organizational Vision. Sloan Management Review, 37(4): 83-91.

33. Lussier, R. N., \& Achua, C. 2000. Leadership. Cincinnati, Ohio: Thomson South-West.

34. Maccoby, M. 2000. Narcissistic Leaders: The Incredible Pros, the Inevitable Cons. Harvard Business Review, 78(1): 68-77.

35. Maccoby, M. 1981. The leader. New York: Simon and Schuster.

36. Mendall, J. S. \& Gerguoy, H. G. 1984. Anticipatory Management or Visionary Leadership: A Debate. Management Planning, 33(November-December): 28-31.

37. Peters, T. J. 1987. Thriving on chaos: Handbook for a management revolution. New York: Harper and Row.

38. Quigley, J. V. 1993. Vision: How leaders develop it, share it, and sustain it. New York: McGraw-Hill.

39. Reardon, K. K. 1991. Persuasion in practice. Newbury Park, California: Sage.

40. Robbins, S. R. \& Duncan, R. B. 1988. The role of the CEO and top management in the creation and implementation of strategic vision. In D. C. Hambrick (Ed.), The executive effect: Concepts and methods for studying top managers: 137-162. Greenwich, CT: JAI Press.

41. Rust, R. T. \& Zahorik, A. J. 1993. Customer Satisfaction, Customer Retention and Market Share. Journal of Retailing, 69 (summer): 193-215.

42. Sashkin, M. 1992. Strategic leadership competencies: An introduction. In R. L. Phillips \& G. Hunt (Eds.). Strategic leadership: A multiorganization-level perspective: 139-160. Westport, CT: Quorum.

43. Senge, P. M. 1990. The fifth discipline: The art and practice of the learning organization. New York: Currency Doubleday.

44. Sergiovanni, T. J. 1990. Adding Value to Leadership Gets Extraordinary Results. Educational Leadership, 47(8): 23-27.

45. Shamir, B., House, R. J., \& Arthur, M. B. 1993. The Motivational Effect of Charismatic Leadership: A Selfconcept based Theory. Organization Science, 4: 577-594.

46. Sitzia, J. \& Wood, N. 1997. Patient Satisfaction: A Review of Issues and Concepts. Social Science Medical, 45(12): 1829-43.

47. Slater, R. 1993. The new GE: How Jack Welch revived an American institution. Homewood, IL: Business One Irwin.

48. Slavitt, D., Stamps, P., Piedmont, E., \& Hasse, A. 1986. Index of work satisfaction. MI: University of Michigan Press.

49. Stangor, C. 1998. Research methods for the behavioral sciences. New York: Houghton Mifflin.

50. Taris, W. T. \& Bok, I. A. 1998. On Gender Specificity of Person Characteristics in Personnel Advertisements: A Study Among Future Applicants. Journal of Psychology, 132(6): 593-610.

51. Tichy, N. M. \& Devanna, M. A. 1986. The transformational leader. New York: Wiley.

52. Tompkins, N. C. 1992. Employee Satisfaction Leads to Customer Service. HR Magazine, 37(11): 93-97.

53. Van Dyck, B. 1996. Employee Satisfaction One Factor of Top Performing Banks. Northwestern Financial Review, 181(19): 5.

54. Wall, B., Solum, R. S., \& Sobol, M. R. 1992. The visionary leader. Rocklin, CA: Prima.

55. Westley, F. \& Mintzberg, H. 1989. Visionary Leadership and Strategic Management. Strategic Management Journal, 10: 17-32.

56. Yeung, A. \& Berman, B. 1997. Adding Value through Human Resources: Reorienting Human Resource Measurement to Drive Business Performance. Human Resource Management, 36(3): 321-335.

57. Yukl, G. A. 1998. Leadership in organizations. New Jersey: Prentice Hall. 


\section{NOTES}

